THE

PITUITARY GLAND 



\section{THE \\ PITUITARY GLAND}

Edited by

G. W. HARRIS, M.A., sc.D., M.D., D.M., F.R.S.

Department of Human Anatomy

University of Oxford

and

B. T. DONOVAN, B.Sc., PH.D.

Department of Neuroendocrinology, Insitute of Psychiatry

The Maudsley Hospital, London

Volume 2

Anterior Pituitary

UNIVERSITY OF GALIFORNIA PRESS

Berkeley and Los Angeles 1966 


\title{
UNIVERSITY OF GALIFORNIA PRESS
}

Berkeley and Los Angeles, Galifornia

Library of Congress Catalog Card Number: 66-19350

The several contributors named on pages ix and $x$ 1966

\author{
Printed in Great Britain by
}

William Clowes and Sons, Limited, London and Beccles 